\title{
A Crowdfunding Platform User Acceptance: An Empirical Examination Of Performance Expectancy, Effort Expectancy, Social Factors, Facilitating Condition, Attitude, And Behavioral Intention
}

\author{
Christian Haposan Pangaribuan ${ }^{1}$, Yuni Sri Wulandar ${ }^{2}$ \\ Faculty of Business, Sampoerna University, Jakarta, Indonesia ${ }^{1,2}$ \\ christian.pangaribuan@sampoernauniversity.ac.id ${ }^{1}$,yuni.wulandari@my.sampoernauniversity.ac.id ${ }^{2}$
}

\begin{abstract}
Crowdfunding has been a valuable alternative source of funding, especially to many initiated social projects. Despite using technology for effective and efficient solutions, not many people are familiar with it. The main purpose of this study is to expand earlier research by investigating the impact of the UTAUT model in creating a crowdfunding project. In this context, data collected from 134 respondents were tested and analysed. Implications are provided to assist crowdfunders in managing people's attitude and intention related to using the platform to participate in creating a crowdfunding project. The result indicates that performance expectancy, effort expectancy, and facilitating conditions significantly affected attitude towards creating a crowdfunding project. Furthermore, attitude gives a significant effect on crowdfunding intention to create a project, and the most dominant factor in this is study is effort expectancy.
\end{abstract}

Keywords: Crowdfunding, Performance Expectancy, Effort Expectancy, Facilitating Conditions, Social Influence.

\section{Introduction}

During crowdfunding's early stages, capital came in the form of donations, but increasingly it takes the form of debt or equity investments targeting for certain people [1]. In Indonesia itself, the phenomenon of crowdfunding started by Koin Peduli Prita in 2009, in which she was sued to court by Omni International Hospital on charges of defamation due to electronic mail containing complaints of his dissatisfaction with the medical treatment at the hospital. The email she wrote spreads from one mailing to another. In this case, Prita was summoned to pay a fine of IDR 204,000,000 by the civil court. The community then took the initiative to help Prita to cover the cost by inviting all levels of society to donate coins[2].

The effort of expectancy from the technology in crowdfunding platform basically allows the project initiator (crowdfunders) and donators to meet online and the funding from the donators goes to those who need without much intervention. Therefore, the use of web-based technology and the knowledge in crowdfunding have become purposeful for the communities to determine their own social projects [1]. 
As crowdfunding grows in size and becomes widely accepted, crowdfunding is fundamentally open to everyone, hence the social factors around the communities indicate have significant effect to the successful project initiated in crowdfunding website. Moreover, crowdfunding emphasizes the digital divide (such as social-economic and age-based) and the social network endorsements that may go viral as crowdfunding attracts a certain type of crowdfunders networked[3].

In order for crowdfunding to work, individuals must have access to reliable broadband Internet or mobile data networks. Therefore, the crowdfunding platform becomes enabling tools that operate freely and facilitate the crowdfunders and investors meet and connected. The implementation of using technology in crowdfunding platform make the process more efficient and effective which may influence more active investors and open up wider audience to support and opens big opportunities. With the support from governments and development organizations, crowdfunding could become a useful tool in the developing world as well as in Indonesia. Crowdfunding is still largely a developed-world phenomenon but it has potential to stimulate innovation[1].

Governments and policy experts worldwide are considering the possible impact of crowdfunding by trying fashion new regulations, equip entrepreneurs with sufficient information, and empowering new technologies to decide if crowdfunding is a viable funding or investment vehicle for the social use[1]. The rate of growth of crowdfunding platform in Indonesia having a positive trends since 2013. It can be seen from the total donations collected by Kitabisa.com (the larger crowdfunding platform in Indonesia) where this platform can reach IDR 7.2 billion in 2015, then 2016 increased by a total of IDR 53.8 billion, and 2017 donations collected reached IDR 206 billion. Until 2017 there are approximately 8.584 campaigns funded and 563,448 total donors combined[4]. Crowdfunding has widely been adopted by various appropriate technology projects as a means of inter-personal fundraising.

As crowdfunding grows in size and becomes widely accepted, it has also been influenced by the emergence of technology. So, in this research the writer wanted to know about the influence of UTAUT (The Unified Theory of Acceptance and Use of Technology) model in crowdfunding phenomenon, hence the background to find out any relationship between the variables and how far the significances are.

\section{Method}

This research methodology use approach which called quantitative approach by conducting the survey through questionnaires. The aimed is to know all variables that have a significant influence on another variable. In this research, the four variables are performance expectancy (X1), effort expectancy (X2), facilitating conditions (X3), social factors (X4), attitude towards crowdfunding project $(\mathrm{Y})$ and Intention to create a crowdfunding project $(\mathrm{Z})$. Figure 1 represents the proposed conceptual model for this study.

The population of this research taken at Java was divided into several provinces, i.e. Jakarta (South Jakarta, East Jakarta, Central Jakarta, West Jakarta, North Jakarta, and Kepulauan Seribu), Banten (Tangerang, Serang), West Java (Bandung, Bekasi, Depok, Bogor), East Java (Surabaya, Malang, Bojonegoro), Central Java (Surakarta, Cilacap, Semarang), and Yogyakarta. Total samples collected were 134 .

The data was collected by distributing the questionnaires on social media (Instagram, WhatsApp, Line, LinkedIn, and Facebook) using the 4-point Likert scale. 


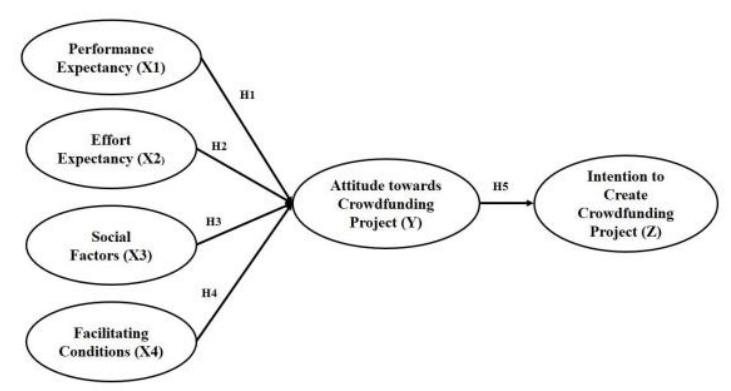

Fig. 1 Framework model.

\section{Result}

Table 1 shows that all items on the questionnaire of all variables are valid (KMO higher than 0.5 ) and reliable ( $\alpha$ higher than 0.8 ).

Table 1. Reliability and validity tests of the variables.

\begin{tabular}{|c|c|c|c|}
\hline Items & $\boldsymbol{\alpha}$ & KMO & $\begin{array}{c}\text { Anti- } \\
\text { image } \\
\text { correlation }\end{array}$ \\
\hline Performance Expectancy & 0.916 & 0.761 & \\
\hline $\begin{array}{l}\text { I am sure Crowdfunding Project (CP) is able to help me get funding } \\
\text { sources }\end{array}$ & & & 0.737 \\
\hline $\mathrm{CP}$ helps me to reach the fundraising target quickly & & & 0.759 \\
\hline $\mathrm{CP}$ increases my productivity in obtaining funding sources & & & 0.735 \\
\hline Using CP increases my chances of getting funding sources & & & 0.819 \\
\hline Effort Expectancy & 0.927 & 0.819 & \\
\hline The website of CP is clear and easy to understand & & & 0.805 \\
\hline The website of CP has structured content & & & 0.828 \\
\hline The CP website helps me when I will create a fund account & & & 0.811 \\
\hline The CP website can be accessed easily & & & 0.835 \\
\hline Social Factors & 0.870 & 0.707 & \\
\hline People around me motivated me to initiate a fundraiser in the $\mathrm{CP}$ & & & 0.695 \\
\hline $\begin{array}{l}\text { Family, friends, and relatives influence me in initiating fundraising } \\
\text { in the CP }\end{array}$ & & & 0.707 \\
\hline $\begin{array}{l}\text { The boss where I work has influenced me in initiating the } \\
\text { fundraising in the CP }\end{array}$ & & & 0.726 \\
\hline $\begin{array}{l}\text { The institution where I go to supports me in initiating a fundraiser } \\
\text { in the CP }\end{array}$ & & & 0.698 \\
\hline Facilitating Conditions & 0.929 & 0.855 & \\
\hline Contact customer service on the $\mathrm{CP}$ provides the services I need & & & 0.819 \\
\hline
\end{tabular}




\begin{tabular}{|l|l|l|r|}
\hline $\begin{array}{l}\text { Customer service on CP can be relied upon in handling the } \\
\text { obstacles that I experience }\end{array}$ & & & 0.855 \\
\hline Customer service on CP has a fast response & & & 0.871 \\
\hline $\begin{array}{l}\text { When experiencing problems, customer service on the CP provides } \\
\text { appropriate feedback }\end{array}$ & & & 0.907 \\
\hline Using CP is the right choice & & & 0.833 \\
\hline Attitude & 0.886 & 0.684 & \\
\hline Using CP makes my work more attractive & & & 0.826 \\
\hline Using CP is really fun & & & 0.623 \\
\hline I love using CP to initiate fundraising & & & 0.665 \\
\hline Behavioral Intention & 0.929 & 0.708 & \\
\hline I want to use this CP someday & & & 0.678 \\
\hline $\begin{array}{l}\text { I want to recommend this CP to relatives, friends and people closest } \\
\text { to me }\end{array}$ & & & 0.871 \\
\hline I will say positive things about CP & & & 0.639 \\
\hline
\end{tabular}

From the total of 134 respondents, 61 are males (45.5\%) and 73 females (54.5\%). In terms of age, 18-24 year olds (88.8\%), 25-34 (9.7\%), 35-44 (0.7\%), and 45-54 (0.7\%). For educational background, 79.1\% holds Bachelor Degree, 11.9\% Senior High School Students, 5.2\% Associate Degree, and 3.7\% Master Degree. For the religion of the respondents, 111 are Moslems (82.8\%), 10 Christians (7.5\%), 6 Hindus (4.5\%), 5 Catholics (5\%), 2 Buddhists (1.5\%). For the places of residents, most people live in Jakarta (52.2\%), followed by West Java (18.7\%), East Java (11.2\%), Banten (7.5\%), Yogyakarta (7.5\%), and Central Java (3.0\%). The most dominant in social media used is Instagram $(67.2 \%)$, followed by Line $(12.7 \%)$, Twitter (12.7\%), Facebook (6.7\%), and WhatsApp (0.7\%). For the project background of the respondents, "Individuals" is still dominant with the total of $72.4 \%$, followed by "Community Non-profit" (22.4\%), "Community for Profit" (2.2\%), "Student Council" (1.5\%), and "Student Clubs" $(0.7 \%)$. For project category, the most is "Social" (51.5\%), followed by "Education" (29.1\%), "Environment" (9.7\%), "Infrastructure" (6.7\%), "Medical" (0.7\%), "Religion" (0.7\%), and "Art and Culture" (1.5\%).

\section{Discussion}

\subsection{F-Test}

Table 2 shows that the sig. value is 0.000 which is less than $\alpha$ of 0.05 indicating that Model 1 is significant. F-test is 23.549 greater than F-table of 2.45 , thus, $\mathrm{H} 0$ is rejected.

Table 2. F-test result for model 1.

\begin{tabular}{|l|c|c|c|c|c|}
\hline \multicolumn{1}{|c|}{ Model } & $\begin{array}{c}\text { Sum } \\
\text { of Sq. }\end{array}$ & df & $\begin{array}{c}\text { Mean } \\
\text { Sq. }\end{array}$ & F & Sig. \\
\hline Regression & 23.146 & 4 & 5.786 & 23.549 & 0.000 \\
\hline Residual & 54.697 & 130 & 0.246 & & \\
\hline
\end{tabular}

Table 3 shows that sig. value is 0.000 which is less than $\alpha$ of 0.05 , indicating that Model 2 is significant. F-test is 110.147 greater than F-table of 3.92, thus, H0 is rejected. 
Table 3. F-test result for model 2.

\begin{tabular}{|l|c|c|c|c|c|}
\hline \multicolumn{1}{|c|}{ Model } & $\begin{array}{c}\text { Sum } \\
\text { of Sq. }\end{array}$ & df & $\begin{array}{c}\text { Mean } \\
\text { Sq. }\end{array}$ & F & Sig. \\
\hline Regression & 19.597 & 1 & 19.597 & 110.147 & 0.000 \\
\hline Residual & 23.485 & 133 & 0.178 & & \\
\hline
\end{tabular}

\subsection{T-Test}

Based on the t-test for model 1, the constant value is 0.296 . The three independent variables X1 (performance expectancy), X2 (effort expectancy), and X4 (facilitating condition) indicated to have positive relationship compared with X3 (social factors) with attitude towards crowdfunding projects. So, this indicates that if social factors increase, it will contribute a negative effect on the attitude towards crowdfunding project. Moreover, the variables that give positive relationship (performance expectancy, effort expectancy, and facilitating conditions), if every time the variables increase, they will give a positive effect on the attitude towards crowdfunding project. Effort expectancy is the most dominant variable that influences the attitude towards crowdfunding project with the total coefficient value of 0.292 , otherwise the social factors are the lowest with the value of 0.118 which influences the attitude towards crowdfunding project.

Table 4. T-test result for model 1.

\begin{tabular}{|c|c|c|c|}
\hline Variable & $\mathbf{B}$ & $\mathbf{t}$ & Sig. \\
\hline (Constant) & 0.296 & 0.97 & 0.334 \\
\hline PE & 0.233 & 2.396 & 0.018 \\
\hline EE & 0.292 & 3.056 & 0.003 \\
\hline SI & 0.118 & 1.899 & 0.060 \\
\hline FC & 0.231 & 2.890 & 0.005 \\
\hline
\end{tabular}

The independent variable in the model 2 is attitude towards crowdfunding project with the total coefficient value of 0.598 . Every time the variable increase, it will give a positive effect on the attitude towards crowdfunding project.

Table 5. T-test result for model 2.

\begin{tabular}{|c|c|c|c|}
\hline Variable & B & t & Sig. \\
\hline (Constant) & 1.497 & 8.232 & 0.000 \\
\hline ACP & 0.598 & 10.495 & 0.000 \\
\hline
\end{tabular}

The two groups in "Social Factors" statistically yielded close difference between them. The students find that the teachers were helpful in promoting the use of animation and storytelling as means of unleashing their creativity in the classroom[5]. The students themselves did not perceive those teachers as being influential, nor did they consider others who are important to them (such as peers, academic supervisors, university managers, and academic administrators) as having an influence on their intention. The social factors had no impact on one's intention to use e-journal [6]. They considered e-journal as important elements to support their study, so that in using e-journal, they had internal motivation instead of other's persuasion, pressure or other external factors. Therefore, motivation in creating a project in crowdfunding platform comes 
from their internal factor which is their own desire without any persuasion, pressure or other external factors.

Table 6. Independent sample t-test for social factor.

\begin{tabular}{|c|c|c|c|c|c|}
\hline Category & N & Mean & $\begin{array}{c}\text { Std. } \\
\text { Dev. }\end{array}$ & $\begin{array}{c}\text { Sig. } \\
\text { Levene's } \\
\text { Test }\end{array}$ & $\begin{array}{c}\text { Sig. } \\
\text { 2- } \\
\text { tailed }\end{array}$ \\
\hline Gender & & & & & \\
\hline Male & 61 & 2.77 & 0.79 & 0.62 & 0.96 \\
\hline Female & 73 & 2.78 & 0.74 & & \\
\hline Age & & & & & \\
\hline $18-24$ & 119 & 2.81 & 0.77 & 0.20 & 0.22 \\
\hline Others & 15 & 2.55 & 0.64 & & \\
\hline Education & & & & & \\
\hline Undergrads & 106 & 2.79 & 0.76 & 0.90 & 0.83 \\
\hline Others & 28 & 2.75 & 0.78 & & \\
\hline Proj. Init. & & & & & \\
\hline Social & 68 & 2.74 & 0.75 & 0.64 & 0.51 \\
\hline Others & 66 & 2.82 & 0.78 & & \\
\hline Domicile & & & & & \\
\hline Jakarta & 70 & 2.83 & 0.74 & 0.70 & 0.42 \\
\hline Others & 64 & 2.72 & 0.78 & & \\
\hline
\end{tabular}

\subsection{Theoretical implications}

From Model 1 of this study, only one variable (Social Factors) that is not significant and does not have positive relationship to attitude towards crowdfunding project. Also, this result was in line with previous studies[7]. This is relevant due to the effort expectancy comes as the most variable that affect the attitude towards crowdfunding project, meaning that the respondents tend to strongly agree if crowdfunding platform is easy to use. Based on the findings, it shows that this research completely gives yet another evidence that the UTAUT Model can be utilized in understanding the intention to create project in the crowdfunding platform. The facilities also determine the intention in creating a project, e.g. reliable Internet connection for browsing and accessing the crowdfunding website. The influence of attitude towards crowdfunding project towards intention shows that the UTAUT Model is proven to have impact on the intention to create a crowdfunding project.

\subsection{Managerial implications}

Crowdfunding comes as the solution to gain funding in effective and efficient way. During crowdfunding's early stages, capital came in the form of donations, but increasingly it takes the form of debt or equity investments targeting high-growth entrepreneurs - only one of many ways the model is evolving as awareness spreads [1]. This research provides an explanation in how some aspect has influence in people's intention to create project in crowdfunding platform. Technology has helped crowdfunders to get a better understanding and good insight in the platform used. The crowdfunders tend to use crowdfunding platform to get funding rather than 
through donation based. Thus, it opens great opportunities for successful crowdfunding platforms. Furthermore, since the research undertaken in Java, it gives new insight for college students, public figure, social activist, community profit or non-profit in this area to implement the crowdfunding idea as a solution to gain more funding to their project. The use of crowdfunding platform has indicated that the easier to use and more understandable a platform, the better it is to help people in initiating their own crowdfunding project.

Throughout 2017, funding and online donations are increasingly popular in Indonesia, and more than 12,000 online fundraising campaigns were created during this year. The most important highlights are how Internet penetration is in line with the public who are increasingly familiar with online fundraising activities as a solution to various funding problems. Kitabisa.com comes as an alternative solution in gaining more fund and well known as a crowdfunding platform that provides reliable services. Through Kitabisa.com, there have been at least 12,000 campaigns initiated, $72 \%$ of donations come from mobile, and a total donation of 193 billion rupiahs. This proves that if there is a lot of hope through crowdfunding platforms and through technology it will be increasingly evident with the large number of people participating in enlivening the campaign.

\section{Conclusion}

According to the results, Model 1 in this research indicates that effort expectancy comes as the most variable affecting the attitude towards crowdfunding project. Model 2 describes the attitude towards crowdfunding project having positive relationship to create project in the crowdfunding platform.

\section{References}

[1] W. B. W. Bank, Overcoming Drought. World Bank Publications, 2006.

[2] M. Anshari dan M. N. Almunawar, "Evaluating CRM Implementation in Healthcare Organization," dalam Proceedings of 2011 International Conference on Economics and Business Information, 2011.

[3] S. H. Gelfond dan A. D. Foti, "US \textdollar500 and a click: investing the 'crowdfunding' way," J. Invest. Compliance, vol. 13, no. 4, hlm. 9-13, Nov 2012.

[4] Kitabisa.com, "Indonesia Online Giving Report," 2018. .

[5] J. T. Marchewka, C. Liu, dan K. Kostiwa, "An Application of the UTAUT Model for Understanding Student Perceptions Using Course," Manag. Softw. Commun. IIMA, 2007.

[6] T. Muhsin, P., dan A. Nurkhin, "Intention to use E-Journal; A Unified Theory of Acceptance and use of," Technol. Perspect. IOSR J. Res. Method Educ. IOSR-JRME, vol. 6, no. 4, hlm. 100-106, 2016.

[7] T. D. Devon, L. Singh, dan K. Gaffar, "The Utility of the UTAUT Model In Explaining Mobile Learning Adoption In Higher Education," Guyana Int. J. Educ. Dev. Using Inf. Commun. Technol., vol. 9, no. 3, hlm. 71-85, 2013. 